\title{
Pemahaman dan Pembelajaran Tahap Perencanaan dan Penyiapan Pembangunan Infrastruktur di Indonesia Melalui Skema Kerja Sama Pemerintah dan Badan dalam Penyediaan Infrastruktur (KPBU)
}

\author{
Mochamad Rifki Maulana \\ Magister Hukum Ekonomi, Universitas Indonesia \\ m.rifki91@ui.ac.id,rifkimaulanaya@gmail.com
}

\begin{abstract}
Abstrak. Kerja Sama Pemerintah dengan Badan Usaha dalam Penyediaan Infrastruktur (KPBU) merupakan skema pambiayaan infrastruktur yang sering terdengar setidaknya dalam lima tahun terakhir di Indonesia. Keterbatasan dana dan optimalisasi menjadi salah satu alasan skema ini menjadi populer saat ini. Pemahan terhadap prinsip dan tahapan KPBU merupakan hal penting bagi masyarakat untuk mengenal dan mengetahui perkembangan skema pembiayaan infrastruktur di Indonesia saat ini. Hal tersebut dapat ditemui di tahap perencanaan dan penyiapan Proyek KPBU. Metodologi dalam tulisan ini bersifat deskriptif normatif, dengan tujuan penulisan berfokus untuk mengetahui skema KPBU dari segi perencanaan dan penyiapan berdasarkan regulasi Perpres 38 Tahun 2015 dan peraturan turunan terbarunya serta melihat pembelajaran yang dapat diambil. Kesimpulan dari tulisan ini adalah sebagai upaya percepatan pembangunan dan penyediaan infrastruktur, Pemerintah Indonesia merubah paradigma pembangunan dengan menjadikan skema KPBU menjadi pilihan utama dalam opsi pembiayaan infrastruktur dan untuk mempercepat pelaksanaannya dibutuhkan perhatian lebih oleh pengambil keputusan.
\end{abstract}

Kata Kunci: Pembiayaan Pembangunan, Infrastruktur, Kerja Sama Pemerintah Dengan Badan Usaha (KPBU)

Abstract. Public Private Partnership (PPP) is an infrastructure financing scheme that has often been heard of at least in the last five years in Indonesia. Limited funds and optimization are one of the reasons this scheme has become popular today. Understanding the principles and stages of PPP is important for the public to know about the current development of infrastructure financing schemes in Indonesia. This can be found at the PPP Project Planning and Preparation stage. The methodology in this paper is descriptive normative, with the aim of focusing on knowing the PPP scheme in terms of planning and preparation based on Presidential Regulation 38 of 2015 and its latest derivative regulations and seeing lessons that can be taken. The conclusion of this paper is that as an effort to accelerate development and provision of infrastructure, the Government of Indonesia is changing the development paradigm by making the PPP scheme the main choice in infrastructure financing options and to accelerate its implementation requires more attention by decision makers.

Keywords: development financing, infrastructure, Public Private Partnership (PPP)

\section{PENDAHULUAN}

Indonesia merupakan negara ekonomi terbesar ke-16 di tahun 2015 dengan nilai Produk Domestik Bruto (PDB) mencapai USD 861,9 Milyar (worldbank.org,2016). Perkembangannya, ditahun 2018, Indonesia masih menempati urutan ke-16 dengan nilai PDB mencapai USD 1,042 Trillion dan di tahun 2019 menurut data International Monetary Fund (IMF) Indonesia masih berada di urutan ke-16 dengan nilai PDB sebesar USD
1,21 Trillion. Bahkan menurut Badan Pusat Statistik (BPS) rata-rata pendapatan orang Indonesia per tahun atau pendapatan per kapita mencapai 3.927 dollar AS atau sekitar Rp 56 juta pada tahun 2018. Angka pendapatan tersebut naik dibandingkan tahun sebelumnya yang hanya 3.876 dollar AS atau Rp 51,9 juta per tahun. Hal ini mengantar Indonesia naik peringkat ke kelompok negara dengan pendapatan menengah ke atas (upper-middle income) menurut versi Bank Dunia. 
Pemerintah Indonesia telah merencanakan untuk masuk ke dalam negara kategori high income country pada tahun 2025. Disisi lain, menurut Darmin Nasution saat menjabat sebagai Menteri Koordinator Bidang Perekonomian (2019), mengatakan Indonesia harus terlebih dahulu keluar dari kategori negara berpenghasilan menengah sebelum tahun 2045 untuk menghindari middle income trap. Hal tersebut bergantung salah satunya pada perkembangan penyediaan infrastruktur di Indonesia.

Kementerian Pekerjaan Umum dan Perumahan Rakyat (PUPR) menyatakan stok infrastruktur Indonesia terhadap Produk Domestik Bruto (PDB) masih jauh dari standar internasional. Berdasarkan data Badan Perencanaan dan Pembangunan Nasional (Bapenas) tahun 2019 tercatat, stok infrakstruktur Indonesia terhadap PDB meningkat dari $35 \%$ pada 2015 menjadi $43 \%$ di awal tahun 2019, Namun angka tersebut masih jauh dari rata- rata stok infrastruktur di negara-negara lainnya mencapai $70 \%$. Menurut World Economics Forum (2019) daya saing infrastruktur Indonesia di kawasan Asia berada pada urutan 72 dari 140 negara. Sedangkan jika dibandingkan dengan negaranegara di kawasan Asia Tenggara dan China, daya saing infrastruktur Indonesia berada di peringkat kelima, setelah Singapura, Malaysia, China dan Thailand. Sedangkan secara global, menurut World Economic Forum (2014), peringkat daya saing global Indonesiapada tahun 2014 - 2015 menempati peringkat 34 dari 114 negara. Di tahun sebelumnya, Indonesia menempati peringkat 38 , artinya Indonesia naik 4 tingkat dari posisi sebelumnya. Namun data di tahun 2018, Indonesia turun ke posisi 45 dan semakin parah di tahun 2019 turun ke posisi 50. Tidak hanya penurunan peringkat, skor daya saing Indonesia juga turun meski tipis 0,3 poin ke posisi 64,6. Peningkatan daya saing ini berbanding sejajar dengan prospek pertumbuhan ekonomi. Cara yang paling tepat untuk meningkatkan daya saing adalah pembangunan infrastruktur.

$\begin{array}{ccc}\begin{array}{c}\text { Pemerintah } \\ \text { memperlihatkan }\end{array} & \begin{array}{c}\text { Indonesia } \\ \text { keseriusannya }\end{array} & \begin{array}{c}\text { sudah } \\ \text { dalam }\end{array}\end{array}$

mengejar ketertinggalan infrastruktur. Hal ini terlihat dalam 4 tahun pertama periode jabatan Presiden Jokowi di masa RPJMN 2015 - 2019, Rencana Kerja Pemerintah (RKP) menitikberatkan pada percepatan pembangunan infrastruktur dan ekonomi. Pada Tahun 2016, pemerintah memperkirakan kebutuhan investasi sebesar Rp 4.411 - 4.431 Trilliun dan mengandalkan APBN/D sebagai sumber utama dalam bentuk pengeluaran modal pemerintah (14.7\%) dan didukung dengan pembiayaan investasi masyarakat, antara lain berasal dari perbankan $(23,8 \%)$, obligasi pemerintah $(16 \%)$, dan aliran modal asing $(19,7)$. Di tahun 2018 pemerintah memastikan kebutuhan pembangunan infrastruktur untuk tahun 2015-2019 menjadi sekitar Rp 4.796 Trilliun dengan taksiran pemenuhan sumber pendanaan yang berasal dari APBN/APBD sebesar Rp 1.978,6 Triliun. Paradigma baru pun muncul di tahun 2018 dimana dalam pendanaan infrastruktur APBN/APBD dijadikan suberdaya terakhir (last resource). Pendanaan infrastruktur diutamakan melalui skema Pembiayaan Investasi Non-Anggaran Pemerintah (PINA) serta Kerja Sama Pemerintah dan Badan Usaha (KPBU).

Pada perkembangannya, sasaran pembangunan infrastruktur tahun 2020 - 2024, Indonesia membutuhkan total kebutuhan investasi infrastruktur sebesar Rp 6.445 Triliun dengan dana yang dimiliki Pemerintah hanya sebesar Rp 2.385 Triliun yang terdiri dari APBN dan APBD. Untuk mengatasi adanya gap pendanaan sebesar Rp 4.059 Triliun, Pemerintah Indonesia memerlukan sumber dana alternatif seperti dari BUMN dan Swasta (Bappenas, 2019) Salah satu upaya yang telah dilakukan Pemerintah untuk meningkatkan peran swasta dengan pemberian insentif dan perizinan dalam penyediaan infrastruktur serta melalui KPBU.

KPBU saat ini dijadikan arus utama pemerintah dalam proses pengembangan alternatif atau creative financing dalam penyediaan infrastruktur. Banyak sekali hal yang melatarbelakangi kebijakan ini muncul, disamping kelebihan dan kekurangan skema KPBU itu sendiri. Konsep kerja sama pemerintah dengan badan usaha sebenarnya 
sudah ada sejak lama, tepatnya dimulai saat pembangunan poyek Jalan Tol Jakarta - Bogor - Ciawi dimana pengaturannya pada saat itu belum jelas. Baru lah pada tahun 1998 lewat Keputusan Presiden Nomor 7 Tahun 1988 tentang Kerjasama Pemerintah Dan Badan Usaha Swasta Dalam Pembangunan Dan Atau Pengelolaan Infrastruktur yang terus berkembang dan hingga saat ini dipayungi oleh Peraturan Presiden Nomor 38 Tahun 2015 tentang Kerja Sama Pemerintah dengan Badan Usaha dalam penyediaan infrastruktur (Perpres 38 Tahun 2015).

Pada saat pertama kali Perpres 38 Tahun 2015 diundangkan, beberapa proyek pemerintah diarahkan untuk menggunakan skema tersebut sebagai pilot project KPBU. Beberapa contoh proyek tersebut antara lain Pembangkit Listrik Jawa Tengah, Sistem Penyediaan Air Minum (SPAM) Umbulan di Jawa Timur, dan Jaringan Fibber Optic Palapa Ring. Proyek-proyek tersebut sukses menghasilkan contoh proyek yang di dapat dikerjasamakan dengan skema KPBU di tahun 2016-2017 terlebih dalam proses tahapannya. Di 1-2 tahun setelahnya, pemerintah terus mensosialisasikan skema KPBU kepada Kementerian/Lembaga dan Kepala Daerah sebagai salah satu skema penyediaan infrastruktur dan upaya pemenuhan layanan kepada masyarakat. Menariknya adalah di akhir tahun 2018 pemerintah telah menyelenggarakan peroyek KPBU dengan jumlah lebih dari 40 proyek, baik yang masih ditahap perencanaan, sedang tahap penyiapan dan transaksi, serta proyek yang sudah ada pemenangnya dan sedang konstruksi.

Kondisi Indonesia dan dunia saat ini sedang dilanda pandemi Covid-19 yang salah satunya mengakibatkan turunnya kapasitas fiskal pemerintah dan daya beli masyarakat. Namun disatu sisi pelayanan tetap harus diberikan sebagai upaya pemenuhan kesehatan dan pemulihan ekonomi. Menarik untuk mengenal skema KPBU yang diindikasi sebagai salah satu skema yang dapat memperingan beban pemerintah dalam penyediaan infrastruktur namun tepat guna dalam melayani masyarakat ditengah keterbatasan fiskal yang saat ini sedang dialami. KPBU dapat berasal dari Pemerintah (Solicited) atau usulan datang dari Badan Usaha (Unsolicited). Sesuai regulasi, untuk memulai pengerjaan suatu proyek dengan skema KPBU dilakukan tahap perencanaan dan penyiapan terlebih dahulu untuk melihat kelayakan proyek (feasible). Data Bappenas tahun 2020 menunjukan terdapat 45 proyek yang sedang disiapkan Pemerintah dan 13 usulan proyek yang sedang disiapkan Badan Usaha. Penulis merasa tertarik untuk membahas lebih lanjut apa itu KPBU dan bagaimana proses perencanaan dan penyiapan KPBU serta pembelajaran apa yang dapat diambil pada artikel ini dengan rumusan masalah sebagai berikut:

1. Bagaimana pengenalan KPBU secara umum di Indonesia?

2. Bagaimana pengaturan dan apa saja kegiatan yang dilakukan dalam tahap perencanaan dan penyiapan KPBU?

3. Pembelajaran apa yang dapat diambil sebagai evaluasi dalam penyelenggaraan KPBU di Indonesia?

Dalam artikel ini, tujuan umum penulis yaitu untuk menambah pengetahuan dan wawasan mengenai Hukum Ekonomi. Sedangkan tujuan khusus dalam artikel ini adalah:

1. Untuk mengetahui skema KPBU secara umum;

2. Untuk mengetahui tahapan perencanaan dan penyiapan pada skema KPBU; dan

3. Untuk mengetahui pembelajaran yang dapat diambil untuk evaluasi penyelenggaraan KPBU di Indonesia.

\section{METODE PENELITIAN}

Metode yang digunakan dalam penulisan artikel ini adalah metode pendekatan deskriptif normatif. Deskriptif normatif yaitu penulisan karya ilmiah yang menjelaskan atau menggambarkan suatu keadaan didasarakan pada studi kepustakaan dan telaah konsep, pendapat ataupun penemuan yang berhubungan dengan permasalahan yang diangkat dalam topik penulisan. Penulis menggambarkan peraturan, konsep dan pendapat hukum berdasarkan bahan hukum 
secara studi kepustakaan yang berkaitan dengan KPBU.

\section{HASIL DAN PEMBAHASAN Pengenalan Skema KPBU (Umum)}

Setelah terpilihnya kembali sebagai Presiden, maka Bapak Presiden Jokowi menjalankan tugasnya sebagaimana dimaksud dalam Pasal 4 ayat (1) UUD 1945 yang menyatakan bahwa Presiden Republik Indonesia memegang kekuasaan pemerintah menurut Undang-Undang Dasar. Dalam rangka melanjutkan pembangunan, Presiden perlu Menyusun rencana pembangunan jangka menengah tahun 2020-2024 sebagai amanat dari Undang-Undang Nomor 25 Tahun 2004 tentang Sistem Perencanaan Pembangunan Nasional (UU SPPN). Pasal 19 ayat (1) UU SPPN menyatakan bahwa Rencana Pembangunan Jangka Menengah Nasional (RPJMN) ditetapkan paling lambat 3 (tiga) bulan setelah Presiden dilantik. Dengan dasar tersebut, maka Presiden menetapkan Peraturan Presiden Nomor 18 Tahun 2020 tentang Rencana Pembangunan Jangka Menengah Nasional Tahun 2020-2024. Peraturan Presiden Nomor 18 Tahun 2020 terdiri dari peraturan itu sendiri dan 4 buah lampiran dimana lampiran pertama berisi Narasi RPJMN Tahun 2020 - 2024, Lampiran 2 berisi Proyek Prioritas Strategis (Major Project), Lampiran 3 berisi Matriks Pembangunan dan Lampiran 4 berisi Arah Pembangunan Wilayah RPJMN Tahun 2020-2024.

Seperti yang sudah dijelaskan pada pendahuluan, Tahun 2020-2024 kebutuhan belanja infrastruktur mencapai $\mathrm{Rp} 6.445$ Triliun dan kemampuan pemerintah dalam menyediaan sumber pembiayaan hanya mencapai Rp 2.385 Triliun (37\%) dan kapasitas BUMN/D hanya sekitar Rp 1.353 Triliun. Salah satu upaya yang dilakukan oleh Pemerintah, Presiden Jokowi sudah mengeluarkan Perpres 38 Tahun 2015 tentang Kerja Sama Pemerintah dengan Badan Usaha dalam Penyediaan Infrastruktur. Sampai sekarang, Perpres ini merupakan dasar hukum pelaksanaan skema Kerja Sama Pemerintah dengan Badan Usaha dalam Penyediaan
Infrastruktur (KPBU). Latar belakang dibentuknya Perpres 38 Tahun 2015 adalah:

1. Ketersediaan infrastruktur yang memadai dan berkesinambungan dinilai sudah merupakan kebutuhan mendesak, ditambah untuk mendukung pelaksanaan pembangunan nasional dalam rangka meningkatkan perekonomian nasional, menyejahterakan masyarakat, dan meningkatkan daya saing Indonesia dalam persaingan global;

2. Untuk mempercepat pembangunan infrastruktur, perlu mengambil langkahlangkah yang komprehensif guna menciptakan iklim investasi serta untuk mendorong keikutsertaan badan usaha dalam penyediaan infrastruktur dan layanan berdasarkan prinsip-prinsip usaha yang sehat; dan

3. Dalam mendorong dan meningkatkan kerjasama antara pemerintah dan badan usaha dalam penyediaan infrastruktur dan layanan sosial, diperlukan pengaturan guna melindungi dan menjaga kepentingan konsumen, masyarakat, dan badan usaha secara berkeadilan. adalah:

Tujuan dari dilaksanakannya KPBU

1. Mencukupi kebutuhan pendanaan secara berkelanjutan dalam Penyediaan Infrastruktur melalui pengerahan dana swasta;

2. Mewujudkan Penyediaan Infrastruktur yang berkualitas, efektif, efisien, tepat sasaran, dan tepat waktu;

3. Menciptakan iklim investasi yang mendorong keikutsertaan Badan Usaha dalam Penyediaan Infrastruktur berdasarkan prinsip usaha secara sehat;

4. Mendorong digunakannya prinsip pengguna membayar pelayanan yang diterima, atau dalam hal tertentu mempertimbangkan kemampuan membayar pengguna; dan/atau

5. Memberikan kepastian pengembalian investasi Badan Usaha dalam Penyediaan Infrastruktur melalui mekanisme pembayaran secara berkala oleh pemerintah kepada Badan Usaha. 
Jika merujuk pada Narasi RPJMN 2020-2024, penyediaan layanan dasar seperti rasio elektrifikasi, akses air minum layak, akses sanitasi layak dan keterjangkauan sinyal adalah $100 \%$. Hal tersebut menandakan penyediaan infrastruktur untuk mengadakan pelayanan dasar wajib disediakan oleh pemerintah. Untuk mencapai target-target pembangunan ketersediaan infrastruktur maka keterlibatan Badan Usaha di luar Pemerintah sangat diperlukan.

Menurut Pasal 1 angka 6 Perpres 38 Tahun 2015, Kerjasama Pemerintah dengan Badan Usaha (KPBU) adalah kerjasama antara pemerintah dan Badan Usaha dalam Penyediaan Infrastruktur untuk kepentingan umum dengan mengacu pada spesifikasi yang telah ditetapkan sebelumnya oleh Menteri/ Kepala Lembaga/Kepala Daerah/Badan Usaha Milik Negara/Badan Usaha Milik Daerah, yang sebagian atau seluruhnya menggunakan sumber daya Badan Usaha dengan memperhatikan pembagian risiko diantara para pihak. Jika dilihat dari pengertian diatas setidaknya ada 5 (lima) unsur yang harus ada dalam KPBU itu sendiri, diantaranya:

1. KPBU merupakan Kerjasama antara Pemerintah dengan Badan Usaha. Proyek dengan skema KPBU bukan privatisasi sebab pemilik proyek adalah pemerintah (penanggung jawab). Pihak swasta terlibat untuk hal-hal tertantu seperti mendesain, membangun, membiayai, dan mengelola (Design, Build, Finance, Operation, Maintenance/DBFOM) sesuai aturan sektor yang berlaku. Kerja sama tersebut dituangkan dalam suatu perjanjian keperdataan dimana syarat sah perjanjian diatur secara tegas dalam pasal $1320 \mathrm{KUH}$ Perdata;

2. Skema KPBU ditujukan untuk pemenuhan kebutuhan masyarakat atau untuk kepentingan umum. Prinsipnya, proyek dengan skema KPBU dikerjakan untuk memenuhi kewajiban pemerintah dalam penyediaan layanan kepada masyarakat. Hal tersebut berimplikasi pada subjek pengaturan berikutnya yaitu adanya spesifikasi yang ditetapkan sebelumnya. Hal tersebut semata-mata ditujukan untuk pemenuhan kebutuhan layanan masyarakat yang lebih baik;

3. Ada spesifikasi yang ditetapkan oleh Penanggung Jawab Proyek Kerjasama (PJPK). Untuk memenuhi kebutuhan masyarakat dengan pelayanan terbaik, pemerintah menetapkan rancangan dasar (basic design) untuk pengadaan dan badan usaha diberikan kebebasan untuk menentukan detail rancangannya. Hal ini menunjukan proyek yang dilaksanakan berbasis hasil (output based). Pemerintah sebagai pemilik proyek juga menentukan layanan minimal yang harus disediakan oleh Badan Usaha (service level agreement/SLA). Jika Badan Usaha tidak memberikan pelayanan sebagaimana yang diminta pemerintah, maka pemerintah tidak mempunyai kewajiban membayar kepada Badan Usaha atau jika Badan Usaha memberikan layanan dibawah SLA yang disepakati maka Pemerintah berhak mengurangi kompensasi yang diperjanjikan;

4. Sumber daya sebagian atau seluruhnya berasal dari pihak swasta. Salah satu kelebihan suatu proyek dilaksanakan dengan skema KPBU adalah penggunaan anggaran pihak swasta untuk membangun infrastruktur. Dalam hal ini pemerintah dapat mengambil keuntungan berupa penghematan anggaran yang digunakan untuk membangun infrastruktur atau anggaran yang sudah ada dapat digunakan untuk membangun infrastruktur lain (leverage project);

5. Ada pembagian risiko antara pemerintah dan badan usaha. Salah satu kelebihan lain skema KPBU adalah adanya pembagian risiko yang didasarkan pada prinsip pihak yang dapat mengendalikan risiko lebih baik merupakan pihak yang akan menanggung risiko tersebut. Contoh pelaksanaan skema KPBU, ketika pihak swasta membangun sebuah infrastruktur jalan tola tau kebandarudaraan, maka risiko konstruksi, keterlambatan pembangunan dan hal teknis lainnya akan menjadi risiko pihak swasta. Tetapi risiko politik seperti pergantian Menteri/Kepala 
Lembaga/ Kepala Daerah maupun pergantian regulasi menjadi tanggung jawab pemerintah. Pembagian risiko memberikan keuntungan kepada masingmasing pihak. Pada satu sisi, pemerintah tidak harus memikirkan penambahan anggaran jika ada keterlambatan pembangunan karena pembangunan merupakan tanggung jawab penuh dari Badan Usaha. Di sisi lain, pihak swasta juga lebih pasti dalam melaksanakan pembangunan karena risiko-risiko politik ditanggung pemerintah. Di dalam skema KPBU juga terdapat fasilitas Penjaminan Pemerintah yang diatur dalam Peraturan Presiden Nomor 78 Tahun 2010 Tentang Penjaminan Infrastruktur Dalam Proyek Kerja Sama Pemerintah Dengan Badan Usaha yang Dilakukan Melalui Badan Usaha Penjaminan Infrastruktur (PT PII).

Hal ini diekstraksi ke dalam prinsipprinsip KPBU yang meliputi:

1. Kemitraan, yakni kerjasama antara pemerintah dengan Badan Usaha dilakukan berdasarkan ketentuan peraturan perundang-undangan dan persyaratan yang mempertimbangkan kebutuhan kedua belah pihak;

2. Kemanfaatan, yakni Penyediaan Infrastruktur yang dilakukan oleh pemerintah dengan Badan Usaha untuk memberikan manfaat sosial dan ekonomi bagi masyarakat;

3. Bersaing, yakni pengadaan mitra kerjasama Badan Usaha dilakukan melalui tahapan pemilihan yang adil, terbuka, dan transparan, serta memperhatikan prinsip persaingan usaha yang sehat;

4. Pengendalian dan pengelolaan risiko, yakni kerja sama Penyediaan Infrastruktur dilakukan dengan penilaian risiko, pengembangan strategi pengelolaan, dan mitigasi terhadap risiko;

5. Efektif, yakni kerja sama Penyediaan Infrastruktur mampu mempercepat pembangunan sekaligus meningkatkan kualitas pelayanan pengelolaan dan pemeliharaan infrastruktur; dan

6. Efisien, yakni kerja sama Penyediaan Infrastruktur mencukupi kebutuhan pendanaan secara berkelanjutan dalam Penyediaan Infrastruktur melalui dukungan dana swasta.

Secara regulasi, KPBU yang dipayungi oleh Perpres 38 Tahun 2015 telah melahirkan peraturan-peraturan pelaksana dibawahnya. Bahkan sudah cukup banyak regulasi penyempurna dari regulasi pertama yang dikeluarkan sebagai peraturan pelaksana KPBU. Peraturan-peraturan tersebut dapat dirangkum sebagai berikut:

1. Peraturan Menteri Perencana Pembangunan Nasional/Kepala Badan Perencanaan Pembangunan Nasional (Bappenas) Nomor 4 Tahun 2015 sebagaimana telah diubah oleh Peraturan Menteri Perencana Pembangunan Nasional/Kepala Badan Perencanaan Pembangunan Nasional (Bappenas) Nomor 2 Tahun 2020 tentang Tata Cara Pelaksanaan Kerja Sama Pemerintah dengan Badan Usaha dalam Penyediaan Infrastruktur (Permen PPN 2 Tahun 2020);

2. Peraturan Kepala LKPP Nomor 19 Tahun 2015 tentang Tata Cara Pelaksanaan Pengadaan Badan Usaha Kerja Sama Pemerintah dengan Badan Usaha dalam Penyediaan Infrastruktur;

3. Peraturan Kepala LKPP Nomor 29 Tahun 2018 tentang Tata Cara Pelaksanaan Pengadaan Badan Usaha Kerja Sama Pemerintah dengan Badan Usaha dalam Penyediaan Infrastruktur atas Prakarsa Menteri/Kepala Lembaga/Kepala Daerah;

4. Peraturan Menteri Keuangan Nomor 260 Tahun 2016 tentang Tata Cara Pembayaran Ketersediaan Layanan Pada Proyek Kerja Sama Pemerintah Dengan Badan Usaha Dalam Rangka Penyediaan Infrastruktur;

5. Peraturan Menteri Dalam Negeri Nomor 96 Tahun 2016 tentang Pembayaran Ketersediaan Layanan Dalam Rangka Kerjasama Pemerintah Daerah Dengan Badan Usaha Dalam Penyediaan Infrastruktur Di Daerah;

6. Peraturan Menteri Keuangan Nomor 170 Tahun 2018 tentang Perubahan Atas Peraturan Menteri Keuangan Nomor 
223/PMK.011/2012 Tentang Pemberian Dukungan Kelayakan Atas Sebagian Biaya Konstruksi Pada Proyek Kerja Sama Pemerintah Dengan Badan Usaha Dalam Penyediaan Infrastruktur;

7. Peraturan Menteri Keuangan Nomor 170 Tahun 2015 tentang Perubahan Atas Peraturan Menteri Keuangan Nomor 143/PMK.Ch1/2013 Tentang Panduan Pemberian Dukungan Kelayakan Atas Sebagian Biaya Konstruksi Pada Proyek Kerja Sama Pemerintah Dengan Badan Usaha Dalam Penyediaan Infrastruktur;

8. Peraturan Menteri Keuangan Nomor 180 Tahun 2020 tentang Fasilitas Untuk Penyiapan Dan Pelaksanaan Transaksi Proyek Kerja Sama Pemerintah Dengan Badan Usaha Dalam Penyediaan Infrastruktur;

9. Peraturan Menteri Keuangan Nomor 8 Tahun 2016 tentang Perubahan atas Peraturan Menteri Keuangan Nomor 260/PMK.011/2010 tentang Petunjuk Pelaksanaan Penjaminan Infrastruktur dalam Proyek Kerjasama Pemerintah dengan Badan Usaha;

10. Terdapat peraturan dengan substansi yang tidak jauh berbeda namun peraturan ini dikeluarkan sebagai akibat dari adanya kewenangan seperti;

a. Peraturan Menteri Pekerjaan Umum dan Perumahan Rakyat Nomor 21/PRT/M/2018 tentang Tata Cara Pelaksanaan Kerja Sama Pemerintah dengan Badan Usaha dalam Penyediaan Infrastruktur di Kementerian PUPR;

b. Peraturan Menteri Perhubungan Republik Indonesia Nomor 58 Tahun 2018 Tentang Tata Cara Pelaksanaan Kerja Sama Pemerintah Dengan Badan Usaha Dalam Penyediaan Infrastruktur Transportasi Di Lingkungan Kementerian Perhubungan; dan

c. Peraturan Gubernur DKI Jakarta Nomor 22 Tahun 2018 tentang Penyelenggaraan Kerjasama Pemerintah Daerah Dengan Badan
Usaha Dalam Penyediaan Infrastruktur.

Tata cara pelaksanaan KPBU diatur dalam Permen PPN 2 Tahun 2020. Permen PPN 2 Tahun 2020 merupakan penyempurnaan dari peraturan sebelumnya, yaitu Permen PPN 4 Tahun 2015. Terdapat pengaturan-pengaturan baru seperti penyederhanaan dan kepastian proses/mekanisme KPBU serta menambahkan pasal substansi baru seperti adanya fasilitas yang dapat diberikan oleh instansi/lembaga pemerintah dalam tahapan KPBU, penguatan daftar rencana KPBU, dan menambahkan tahap pelaksanaan KPBU yaitu pelaksanan perjanjian KPBU. Di dalam Permen PPN 2 Tahun 2020 juga sudah diatur lebih jelas dan beragam jenis infrastruktur yang dapat dikerjasamakan (objek) diantaranya:

1. Infrastruktur transportasi, antara lain:

a. Penyediaan dan/atau pengelola-an fasilitas dan/atau pelayanan jasa kebandarudaraan, termasuk fasilitas pendukung seperti terminal penumpang dan kargo;

b. Penyediaan dan/atau pengelola-an fasilitas dan/atau pelayanan jasa kepelabuhanan;

c. Sarana dan/atau prasarana perkeretaapian;

d. Sarana dan/atau prasarana angkutan massal perkotaan dan lalu lintas termasuk terminal dan/atau Pengembangan Kawasan Berorientasi Transit (Transit Oriented Development);

e. Sarana dan/atau prasarana pengujian kendaraan bermotor;

f. Sarana dan/atau prasarana penimbang kendaraan bermotor; dan/atau

g. Sarana dan/atau prasarana pelayaran laut, sungai, dan/atau danau.

2. Infrastruktur jalan, antara lain:

a. Jalan arteri, jalan kolektor dan jalan lokal;

b. Jalan tol;

c. Jembatan tol;

d. Jembatan non tol; dan/atau

e. Penerangan jalan umum. 
3. Infrastruktur sumber daya air dan irigasi, antara lain:
a. Prasarana penampung air beserta bangunan pelengkapnya, antara lain waduk/bendungan dan bendung. saluran pembawa air baku; dan/atau
b. Jaringan irigasi

4. Infrastruktur air minum, antara lain:
a. Unit air baku;
b. Unit produksi;
c. Unit distribusi; dan/atau
d. Investasi teknologi pengoperasi-an dan
pemeliharaan dalam rangka mengupayakan penyelenggaraan SPAM yang efektif dan efisien dengan mekanisme kontrak berbasis kinerja.

5. Infrastruktur sistem pengelolaan air limbah terpusat, antara lain:
a. Unit pelayanan;
b. Unit pengumpulan;
c. Unit pengolahan;
d. Unit pembuangan akhir; dan/atau
e. Saluran pembuangan air, dan sanitasi.

6. Infrastruktur sistem pengelolaan air limbah setempat, antara lain:
a. Unit pengolahan setempat;
b. Unit pengangkutan;
c. Unit pengolahan lumpur tinja;
d. Unit pembuangan akhir; dan/atau
e. Saluran pembuangan air, dan sanitasi.

7. Infrastruktur sistem pengelolaan persampahan dan/atau limbah B3, antara lain:
a. Infrastruktur sistem pengelolaan persampahan, antara lain:
i. Pengangkutan;
ii. Pengolahan; dan/atau
iii. Pemrosesan akhir sampah.

b. Infrastruktur sistem pengelolaan limbah bahan berbahaya dan beracun (B3), antara lain:
i. Pengumpulan;
ii. Penyimpanan; dan/atau
iii. Pengolahan.

8. Infrastruktur telekomunikasi dan informatika, antara lain:
a. Jaringan telekomunikasi;
b. Infrastruktur e-government; dan/atau
c. Infrastruktur pasif seperti pipa saluran media transmisi kabel (ducting).

9. Infrastruktur ketenagalistrikan, antara lain:
a. Pembangkit listrik;
b. Transmisi tenaga listrik;
c. Gardu induk; dan/atau
d. Distribusi tenaga listrik.

10. Infrastruktur minyak dan gas bumi dan energi terbarukan, termasuk bio-energi, antara lain:
a. Pengolahan;
b. Penyimpanan;
c. Pengangkutan; dan/atau
d. Distribusi.

11. Infrastruktur konservasi energi, antara lain:

a. Penerangan jalan umum; dan/atau

b. Efisiensi energi.

12. Infrastruktur ekonomi fasilitas perkotaan, antara lain:
a. Saluran utilitas (tunnel); dan/atau
b. Pasar umum.

13. Infrastruktur kawasan, antara lain:
a. Kawasan pengembangan ilmu pengetahuan, teknologi dan inovasi termasuk pembangunan science and techno park; dan/atau
b. Kawasan industri.

14. Infrastruktur pariwisata, antara lain:

a. Kawasan pariwisata; dan/atau
b. Pusat informasi pariwisata (tourism information center).

15. Infrastruktur fasilitas pendidikan, penelitian dan pengembangan, antara lain:
a. Sarana pembelajaran;
b. Laboratorium;
c. Pusat pelatihan;
d. Pusat penelitian/pusat kajian;
e. Sarana dan prasarana penelitian dan pengembangan;
f. Inkubator bisnis;
g. Galeri pembelajaran;
h. Ruang praktik siswa;
i. Perpustakaan; dan/atau
j. Fasilitas pendukung pembelajaran dan pelatihan.

16. Infrastruktur fasilitas sarana olahraga, kesenian dan budaya, antara lain:

a. Gedung/stadion olahraga; dan/atau

b. Gedung kesenian dan budaya.

17. Infrastruktur kesehatan, antara lain: 
a. Rumah sakit, seperti bangunan rumah sakit, prasarana rumah sakit, dan peralatan medis;

b. Fasilitas pelayanan kesehatan dasar, seperti bangunan, prasarana, dan peralatan medis baik untuk puskesmas maupun klinik; dan/atau

c. Laboratorium kesehatan, seperti bangunan laboratorium kesehatan, prasarana laboratorium kesehatan dan peralatan laboratorium.

18. Infrastruktur pemasyarakatan, antara lain:

a. Lembaga pemasyarakatan;

b. Balai pemasyarakatan;

c. Rumah tahanan negara;

d. Rumah penyimpanan benda sitaan dan barang rampasan negara;

e. Lembaga penempatan anak sementara;

f. Lembaga pembinaan khusus anak;

g. Rumah sakit pemasyarakatan; dan/atau

h. Fasilitas asimilasi.

19. Infrastruktur perumahan rakyat, antara lain:

a. Perumahan rakyat sewa untuk golongan rendah; dan/atau

b. Rumah susun sederhana sewa, antara lain:

i. Rumah susun umum;

ii. Rumah susun khusus; dan/atau

iii. Rumah susun negara.

20. Infrastruktur bangunan negara, antara lain gedung perkantoran, rumah negara, dan sarana pendukung lainnya.

Infrastruktur bangunan negara ini diadakan salah satunya untuk mendukung rencana pembangunan Ibu Kota Negara (IKN) Baru yang saat ini masih dikaji oleh pemerintah.

KPBU juga memiliki Kelembagaan. Pihak yang dapat melakukan kerja sama (subjek) di sisi Pemerintah sebagai PJPK yaitu Menteri, Kepala Lembaga, Kepala Daerah atau Direksi BUMN/BUMD sesuai dengan pengaturan dan kewenangannya masingmasing dan di sisi Badan Usaha yaitu BUMN/BUMD, Badan Usaha Asing, Perseroan Terbatas, dan/atau Koperasi. Perpres 38 tahun 2015 mengatur dalam hal KPBU merupakan gabungan dari 2 atau lebih jenis infrastruktur, penanggung jawab yang memiliki kewenangan terhadap sektor yang dikerjasamakan tersebut bertindak bersamasama sebagai PJPK. Dalam Permen 2 Tahun 2020 diatur lebih lanjut bahwa KPBU dapat merupakan gabungan KPBU yang terdiri dari gabungan dari 2 atau lebih PJPK untuk 1 jenis infrastruktur atau gaubungan dari 2 atau lebih jenis infrastruktur baik yang kewenagannya dimiliki baik oleh Pemerintah Pusat ataupun Pemerintah Daerah. Pelaksanannya para wakil pemerintah tersebut membuat Nota Kesepahaman dan memilih/menunjuk satu perwakilan yang akan menjadi Koordinator PJPK serta menyepakati pembagian peran, pengambilan keputusan, termasuk penganggaran. PJPK dalam melaksanaan KPBU akan dibantu kelembagaan KPBU yaitu Simpul KPBU, Tim KPBU, dan Tim Pengendali Pelaksanaan Perjanjian KPBU.

Simpul KPBU adalah unit kerja di kementerian/lembaga pada tingkat nasional atau unit kerjaa pada tingkat daerah, yang dibentuk baru atau melekat pada unit kerja atau bagian yang sudah ada, dengan tugas dan fungsi perumusaa kebijakan dan/atau sinkronisasi dan/atau koordinasi tahap perencanaan dan tahap penyiapan dan/ atau pengawasan dan evaluasi tahap penyiapan dan tahap transaksi, termasuk pelaksanaan perjanjian KPBU. Praktiknya Simpul KPBU ini dapat berupa unit kerja Eselon 1 Kementerian/Lembaga seperti pada Pusat Fasilitasi Kemitraan dan Kelembagaan Internasional Kementerian Perhubungan. Terdapat pula contoh Simpul KPBU yang melekat pada Sekretaris Daerah sesuai Peraturan Gubernur DKI Jakarta Nomor 22 Tahun 2018 dalam hal KPBU ditingkat pelaksanaan pemerintah daerah. Berbeda dengan Simpul yang melekat pada unti kerja, Tim KPBU dan Tim Pengendali Pelaksanaa Perjanjian KPBU merupakan Tim yang sengaja dibentuk khusus untuk melaksanakan suatu proyek KPBU. Perbedaan dari kedua Tim tersebut terletak pada tugas dan fungsinya dimana Tim KPBU membantu PJPK dalam pengelolaan KPBU pada tahap penyiapan dan transaksi hingga tercapai pemenuhan pembiayaan (financial close), termasuk 
membantu panitia pengadaan dalam kegiatal Pengadaan Badan Usaha Pelaksana, apabila diperlukan. Sedangkan Tim Pengendali adalah tim yang dibentuk atau ditunjuk oleh PJPK untuk membantu PJPK dalam tahap pelaksanaan perjanjian KPBU. Tim ini memiliki efektifitas waktu setelah penandatanganan perjanjian KPBU dilakukan.

Baik prakarsa pemerintah ataupun badan usaha, PJPK menetapkan bentuk pengembalian investasi yang meliputi penutupan biaya modal, biaya operasional, dan keuntungan Badan Usaha Pelaksana (BUP/Investor). Pengembalian investasi BUP bersumber dari:

1. Pembayaran oleh pengguna dalam bentuk tarif;

2. Pembayaran Ketersediaan Layanan (Availability Payment/AP); dan/atau

3. Bentuk lainnya sepanjang tidak bertentangan dengan peraturan perundang-undangan.

Pembayaran Ketersediaan Layanan (AP) adalah pembayaran secara berkala oleh Menteri/Kepala Lembaga/Kepala Daerah kepada BUP atas tersedianya layanan Infrastruktur yang sesuai dengan kualitas dan/atau kriteria sebagaimana ditentukan dalam perjanjian KPBU. Contoh sumber pengembalian dalam bentuk AP biasanya dijumpai pada proyek Rumah Sakit, Penerangan Jalan Umum, dan Sektor Telekomunikasi. Sedangkan untuk contoh sumber pengembalian dalam bentuk tarif sering dijumpai pada proyek Jalan Tol dan SPAM.

Merujuk pada Pasal 10 Permen PPN 2 Tahun 2020, KPBU dilaksanakan melalui tahap perencanaan, penyiapan, transaksi dan pelaksanaan perjanjian KPBU yang lebih rinci diatur sebagai berikut:

1. Perencanaan KPBU yang terdiri dari:

a. Penyusunan rencana anggaran dana KPBU;

b. Identifikasi dan peneteapan KPBU, termasuk untuk gabungan 2 atau lebih PJPK;

c. Penganggaran dana tahap perencanaan; d. Pengambilan keputusan lanjut/tidak lanjut rencana KPBU;

e. Penyusunan Daftar Rencana KPBU;

f. Pengkategorian KPBU; dan

g. Kegiatan penunjang pelaksanann tahap perencanaan KPBU.

2. Penyiapan KPBU terdiri dari:

a. Penyiapan Kajian KPBU;

b. Konsultasi Publik;

c. Penjajakan Minat Pasar;

d. Kegiatan Pendukung, seperti:

i. Pengajuan Dukungan Pemerintah;

ii. Pengajuan Jaminan Pemerintah; dan

iii. Pengajuan Penetapan Lokasi.

3. Transaksi KPBU terdiri dari:
a. Konsultasi Pasar (Market Consultation);
b. Penetapan lokasi KPBU;
c. Pengadaan Badan Usaha Pelaksana KPBU;
d. Penandatanganan perjanjian KPBU; dan
e. Pemenuhan Pembiayaan (Financial Close);

4. Pelaksanaan Perjanjian KPBU terdiri dari:

a. Persiapan pengendalian pelaksanaan Perjanjian KPBU, terdiri dari:

i. penunjukan Tim Pengendali;

ii. penyusunan dan penetapan dokumen petunjuk pengendalian pelaksanaan perjanjian KPBU;

iii. penyerahan segala bentuk dokumentasi yang dihasilkan pada tahap perencanaan, penyiapan dan tralsaksi kepada Tim Pengendali;

iv. koordinasi dengan tim KPBU dalam pelaksanaan kegiatan terkait pemenuhan pembiayaan.

b. Pengendalian Pelaksanaan Perjanjian KPBU. Tahap Pengendalian Pelaksanaan Perjanjian KPBU terdiri dari 3 (tiga) masa yaitu:

i. konstruksi;

ii. penyediaan layanan;

iii. masa berakhirnya Perjaljian KPBU

\section{Perencanaan KPBU}

Secara faktual, di dalam kepemerintahan, untuk memulai suatu 
kegiatan diharuskan untuk disusunnya suatu anggaran. Begitupun KPBU, Dalam penyusunan anggaran dana KPBU, Menteri/ Kepala Lembaga/Kepala Daerah Menyusun rencana anggaran pelaksanaan KPBU dari mulai tahap perencanaan, penyiapan, transaksi dan pelaksanaan perjanjian KPBU. Praktiknya, setiap tahap dilakukan dalam berbeda tahun anggaran, kecuali untuk tahap perencanaan dan penyiapan yang dapat dilakukan dalam satu tahun anggaran. Penyusunan anggaran disetiap tahap pelaksanaan KPBU bertujuan untuk memastikan dan memberikan rambu bahwa anggaran ada di masing-masing lembaga pelaksana KPBU.

Setalah anggaran tersedia, setidaknya untuk tahap perencanaan, eselon satu di unit Kementerian/Lembaga, Kepala Daerah, atau direksi pada BUMN/BUMD melakukan identifikasi proyek yang dapat dikerjasamakan atau sesuai dokumen perencanaan diinisiasi untuk dilakukan dengan skema KPBU. Identifikasi dapat dilakukan dengan membuat daftar proyek yang berasal dari program atau kegiatan pemerintah untuk setelahnya dilakukan prioritisasi dan analisa pemenuhan pembiayaan. Setelah hal tersebut dilakukan, merujuk pada lampiran Permen PPN 2 Tahun 2020 perlu disusun Dokumen Studi Pendahuluan yang meliputi kajian menganai:

1. Analisis Kebutuhan (Need Analysis), meliputi:

a. kebutuhan infrastruktur memiliki dasar pemikiran teknis dan ekonomi dengal permintaan yang berkelanjutan dan diukur dari ketidakcukupan pelayanan, baik secara kuantitas maupun kualitas, berdasarkan ana,lisis data sekunder yang tersedia;

b. identifikasi pilihal dalam penyediaan layanan mencakup lingkup layanan, solusi, ketersediaan penyedia, target pengerjaan, dan skema pembiayaan berdasarkan kebutuhan infrastruktur; dan

c. kepastian KPBU mendapat dukungan dari pemangku kepentingan yang berkaitan, salah satunya melalui Konsultasi Publik.
2. Kriteria Kepatuhan Criteria), meliputi:

a. kesesuaian dengan peraturan perundang-undangan, termasuk penentuan Menteri/Kepala Lembaga/Kepala Daerah/Direksi BUMN/Direksi BUMD bertindak selaku PJPK;

b. kesesuaian KPBU dengan Rencana Pembangunan Jangka Menengah Nasional/ Daerah dan/ atau Rencana Strategis Kementerian/Lembaga, Rencana Kerja Pemerintah Daerah, rencara bisnis BUMN/BUMD;

c. kesesuaian lokasi KPBU dengan Rencana Tata Ruang Wilayah sesuai kebutuhan jenis Infrastruktur yang akan dikerjasamakan; dan

d. keterkaitan antar sektor Infrastruktur dan antar wilayah sesuai kebutuhan jenis Infrastruktur yang akan dikefasamakan.

3. Keriteria faktor penentu nilain manfaat uang (Value for Money), meliputi;

a. sektor swasta memiliki keunggulan dalam pelaksanaan KPBU termasuk dalam pengelolaan risiko;

b. terjaminnya efektivitas, akuntabilitas, dan pemerataan pelayanan publik dalam jangka panjang;

c. alih pengetahuan dan teknologi; dan

d. terjaminnya persaingan sehat, transparansi, dan efisiensi dalam proses pengadaan

4. Analisa potensi pendapatan dan skema pembiayaan proyek, meliputi:
a. kemampuan pengguna untuk membayar;
b. kemampual fiskal Pemerintah, Pemerintah Daerah, BUMN/BUMD dalam melaksanatan KPBU;
c. potensi pendapatan lainnya; dan
d. perkiraan bentuk Dukungan Pemerintah

5. Rekomendasi dan rencana tindak lanjut, meliputi:

a. indikasi bentuk KPBU;

b. rekomendasi hal-hal yang perlu ditindaklanjuti; dan 
c. rencana jadwal kegiatan penyiapan dan transaksi KPBU.

Dokumen Studi Pendahuluan menjadi dokumen penentu suaau proyek dapat dilaksanakan (dengan ukurang lebih efektif dan efisien) dengan skema KPBU atau sebaliknya walaupun Menteri/Kepala Lembaga/Kepala Daerah/ Direksi BUMN /BUMD yang menentukan lanjut atau tidaknya rencana KPBU. Dokumen Studi Pendahuluan memuat paling kurang rencana bentuk KPBU, rencana skema pembiayaan KPBU dan sumber dananya, dan rencana penawaran KPBU yang mencakup jadwal, proses, dan cara penilaian. Dokumen Studi Pendahuluan dapat dikerjakan sendiri oleh instansi calon PJPK, dapat pula menggunakan jasa konsultan, serta dapat memanfaatakan fasilitasi dari Kementerian/ Lembaga/ Instansi tertentu yang memiliki kewenangan dalam memberikan fasilitas penyusunan Dokumen Studi Pendahuluan atau pengadaan konsultan untuk keperluan penyusunan Dokumen Studi Pendahuluan.

Disela penyusunan Dokumen Studi Pendahuluan Menteri/Kepala Lembaga/ Kepala Daerah/Direksi BUMN/BUMD melakukan konsultasi publik untuk mendiskusikan penjelasan dan penjabaran terkait dengan rencana KPBU sehingga diperoleh hasil paling kurang berupa tanggapan dan/atau masukan dari pemangku kepentingan dan evaluasi terhadap hasil yang didapat dari Konsultasi Publik dan implementasinya dalam KPBU. Peserta dari Konsultasi Publik tidak diatur secara pasti namun pada praktiknya Konsultasi Publik dapat dirancang sedemikian rupa tergantung pada tujuang penyelenggaraan menurut Menteri/Kepala Lembaga/ Kepala Daerah/Direksi BUMN/ BUMD. Sebagai contoh terdapat konsultasi publik yang memang diselenggarakan untuk masyarakat yang teridentifikasi terkena dampak dari rencana proyek sehingga memang hanya masyarakat yang diundang dalam kegiatan tersebut. Lain hal terdapat Konsultasi Publik yang dirancang untuk para stakeholder proyek dimana berisi para pemangku kepentingan. Misalkan Konsultasi Publik Proyek Sistem Penyediaan Air Minum (SPAM) Reginal yang meliputi beberapa wilayah kabupaten/kota, maka perwakilan para pemangku kepantingan di wilayah kabupaten/kota yang terkena layanan lah yang diundang, walaupun dapat turut mengundang stakeholder lain seperti calon pelaku industri yang menerima manfaat dari keberadaan SPAM tersebut. Hasil dari Konsultasi Publik tersebut didokumentasikan sebagai catatan penyempurnaan untuk Dokumen Studi Pendahuluan.

Setelah Dokumen Studi Pendahuluan disempurnakan, Menteri/Kepala Lembaga/Kepala Daerah/ Direksi BUMN/BUMD menetapkan proyek untuk dilaksanakan dengan skema KPBU. Pada praktiknya, dokumen penetapan proyek untuk dilaksanakan dengan skema KPBU beragam bentuknya. Ada yang berbentuk Surat Keputusan (SK) terkait pelaksanaan proyek, ada juga yang tidak menggunakan SK namun cukup dengan pembentukan Tim dan Simpul KPBU sebagai komitmen dari PJPK dalam menindaklanjuti proyek untuk dikerjasamakan dengan skema KPBU.

Atas Dokumen Studi Pendahuluan tersebut, Menteri/Kepala Lembaga/Kepala Daerah mengusulkan proyek untuk dimasukan kedalam Daftar Rencana KPBU (DRK) atau yang biasa dikenal dengan PPP Book kepada Menteri Perencana. DRK juga dapat disusun berdasarkan hasil identifikasi Menteri Perencana berdasarkan prioritas pembangunan nasional. Menteri Perencana melakukan seleksi dan penilaian untuk setelahnya DRK ditetapkan terdiri atas KPBU siap ditawarkan dan KPBU dalam proses penyiapan. DRK tersebut menjadi pertimbangan dalam penyusunan Rencana Kerja Pemerintah (RKP) serta dokumen perencanaan lainnya dan pemberian Dukungan \& Jaminan Pemerintah.

Kegiatan pendukung pada tahap perencanaan dapat meliputi identifikasi awal bahwa KPBU menerapkan teknologi dengan dampak lingkungan yang dapat dikelola/dimitigasi dengan baik dan berkelanjutan sesuai referensi literatur dan studi terkait. Lokasi proyek juga dapat ditetapkan setelah atau sebelum kajian akhir diselesaikan berdasarkan dokumen lain yang 
berhubungan (missal RTRW atau dokumen kesesuain perencanaan lainnya).

\section{Penyiapan KPBU}

Setelah tahap perencanaan dan hasil kajian menunjukan proyek dapat/lebih baik dilakukan dengan skema KPBU serta adanya komitmen PJPK untuk terus melaksanakan proyek dengan skema KPBU, PJPK selanjutnya melaksanakan tahap penyiapan KPBU. Tahap ini bertujuan untuk mengkaji kelayakan KPBU untuk dikerjasamakan dengan Badan Usaha. Praktiknya, hal yang utama dilakukan oleh PJPK adalah memastikan ketersediaan anggaran pada tahap penyiapan KPBU untuk penyusunan Prastudi Kelayakan, kajian lingkungan, dan pengadaan badan penyiapan (jika diperlukan) dan Membentuk Tim KPBU sebagai Tim yang membantu PJPK dalam pengelolaan KPBU pada tahap penyiapan dan transaksi hingga tercapai pemenuhan pembiayaan (financial close). Hal tersebut dilakukan guna menentukan dan memudahkan PJPK dalam melaksanakan tahap penyiapan KPBU. Pasalnya jika PJPK tidak memiliki anggaran untuk tahap penyiapan, mitigasi dapat dilakukan sejak dini seperti realokasi anggaran atau menggunakan fasilitasi dari Kementerian/Lembaga/Institusi terkait. Pembentukan Tim KPBU juga dapat memudahkan kerja PJPK dalam pelaksanaan tugas teknis harian serta menjadi narahubung antara PJPK dengan stakeholder terkait.

Seletah hal diatas dilaksanakan barulah proses penyiapan Dokumen Prastudi Kelayakan KPBU dilakukan. Penyiapan Prastudi Kelayakan KPBU dilaksanakan dengan 2 (dua) tahap dengan penyusunan Kajian Awal Prastudi Kelayakan (Outline Business Case) dan dilanjutkan dengan penyusunan Kajian Akhir Prastudi Kelayakan (Final Business Case). Pemisahan penyusunan Dokumen Prastudi Kelayakan tersebut dilatarbelakangi oleh beberapa alasan, diantaranya:

1. Kompleksitas dari suatu proyek itu sendiri. Banyaknya jenis infrastruktur yang dapat dikerjasamakan berimplikasi pada berbedanya tingkat kesulitan dalam menyiapkan proyek. Kesulitan juga terdiri dari berbagai bidang seperti kesulitan teknis, kesulitan struktur proyek, kesulitan komitmen stakeholder, hingga kesulitan finansial proyek;

2. Potensi penggunaan beberapa skema dalam penstrukturan proyek. Kompleksitas proyek berimplikasi terdapatnya beberapa alternatif scenario pada penstrukturan proyek. Oleh sebab itu sering kali Kajian Awal Prastudi Kelayakan berisikan opsi-opsi struktur proyek yang perlu dikaji lebih dalam atau ditentukan di Kajian Akhir Prastudi Kelayakan.

3. Biaya penyiapan proyek. Dokumen penyiapan proyek bukan merupakan dokumen yang murah dan sering kali memakan waktu tidak sebentar dalam pelaksanaannya. Dengan memisahkan kajian, diharapkan biaya penyiapan bisa ditekan dan dapat tejadi penghematan biaya.

Kajian awal Prastudi Kelayakan bertujuan untuk menentukan sasaran dan kendala KPBU, memastikan kesesuaian dengan ketentuan peraturan perundangundangan, mengkaji peran dan tanggung jawab masing-masing pemangku kepentingan, mengkaji pilihan teknis serta ketersediaan teknologi dan barang/jasa yang dibutuhkan, mengidentifikasi pilihan bentuk KPBU terbaik, mengkaji manfaat ekonomi dan sosial dari rencana KPBU, menyusun rencara komersial yang mencakup kajian permintaan (demand), industri (market), struktur pendapatan, dan keuangan; memetakan risiko dan upaya mitigasi yang diperlukan, mengidentifikasi awal atas dampak lingkungan dan sosial, menetapkan persyaratan pelaksanaan KPBU, termasuk landasan hukum, dan tindak lanjut yang diperlukan berkaitan dengan pengadaan tanah dan pemukiman kembali, mengidentifikasi kebutuhan Dukungan Pemerintah dan/atau Jaminan Pe merintah; dan menentukan berbagai permasalahan pokok dan hambatannya serta usulan untuk mengatasi permasalahan. Dikarenakan pada kajian awal 
masih terdapat hal-hal yang perlu dipastikan (firm), oleh sebab itu hal tersebut diputuskan di Kajian Akhir Prastudi Kelayakan dengan tujuan memastikan konsep KPBU dalam kajian awal Prastudi Kelayakan memperoleh persetujuan dari masing-masing pemangku kepentingan; konsep KPBU dalam kqjian awal Prastudi Kelayakan telah dimutakhirkan dan disempurnakan berdasarkan masukan dari Pemerintah, Badan Usaha, masyarakat, lembaga keuangan, dan/atau lembaga terkait lainnya, usulan permintaan Dukungan Pemerintah telah disampaikan oleh PJPK kepada Menteri/Kepala Lembaga/Kepala Daerah dan/ atau Menteri Keuangan apabila hasil kajian awal mengindikasikan perlunya Dukungan Pemerintah untuk KPBU, usulan permintaan Jaminan Pemerintah telah disampaikan oleh PJPK kepada Badan Usaha Penjamin, apabila hasil kajian awal mengidentifikasikan perlunya Jaminan Pemerintah untuk KPBU, Tim KPBU telah terbentuk dan berfungsi, rencana dan jadwal waktu program penyiapan tapak termasuk pengadaan tanah dan program pemukimam kembali telah disiapkan, termasuk rancangan rencana anggaran dan jadwal pelaksanaannya telah diusulkan dalam RKP/D, rancangan rencana anggaran dan jadwal pelaksanaan penyusunan kajian lingkungan (AMDAL atau UKLUPL) telah diusulkan dalam RKP/D; dan langkah untuk menyelesaikan berbagai masalah hukum telah disusun.

$$
\text { Untuk mengakomodir segala }
$$

kebutuhan dijenis/sektor infrastruktur yang ada, pada penyiapan Dokumen Prastudi Kelayakan dapat juga dilaksanakan pengerjaannya secara sekaligus (1 tahap Dokumen Kajian Awal dan Kajian Akhir Prastudi Kelayakan digabung). Kriteria proyek yang dapat dilaksanakan penyiapannya secara 1 tahap adalah proyek merupakan proyek prioritas dan/atau Proyek Strategis Nasional dan/ atau proyek merupakan proyek yang telah memiliki contoh proyek kerja sama serupa dengan minat yang tinggi di dalam Penjajakan Minat Pasar.Dokumen Prastudi Kelayakan berisikan kajian yang meliputi:

1. Kajian Hukum dan Kelembagaan, terdiri dari: a. Analisis peraturan perundang-undangan, yang dilakukan dengan tujuan untuk:

i. Memastikan bahwa KPBU dilaksanakan sesuai dengan ketentuan peraturan perundang-undangan yang berkaitarr dengan aspek:
a) Pendirian Badan Usaha;
b) Penanaman modal;
c) Persaingan usaha;
d) Lingkungan;
e) Keselamatan kerja;
f) Pengadaan tanah;
g) Pembiayaan KPBU, termasuk mekanisme pembiayaan dan pendapatan;
h) Perizinan KPBU;
i) Perpajakan; dan
j) Peraturan terkait lainnya.

ii. Menentukan risiko hukum dan strategi mitigasinya;

iii. Mengkaji kemungkinan penyempurnaan peraturan perundangundangan atau penerbitan peraturan perundang-undangan yang baru;

iv. Mengkaji proses pemanfaatan BMN dan/atau BMD yang diperlukan;

v. Menentukan jenis perizinan/persetujuan yang diperlukan; dan

vi. Menyiapkan rencana dan jadwal untuk memenuhi persyaratan peraturan dan hukum berdasarkan hasil kajian hukum dan kelembagaan.

b. Analisis kelembagaan dengan mengikuti langkah sebagai berikut:

i. Memastikan kewenangan

Menteri/Kepala Lembaga/ Kepala

Daerah/Direksi Badal Usaha Milik Negara/Direksi Badan Usala Milik Daerah sebagai PJPK dalam melaksanakan KPBU termasuk penentuan PJPK dalam proyek multi infrastruktur;

ii. Melakukan pemetaan pemangku kepentingan dengan menentukan peran dan tanggung jawab lembaga yang berkaitan dalam pelaksanaan KPBU;

iii. Menentukan peran dan tanggung jawab Tim KPBU berkaitan dengan kegiatan penyiapan Prastudi Kelayakan, serta 
menentukan sistem pelaporan Tim KPBU kepada PJPK;

iv. Menentukan dan menyiapkan perangkat regulasi kelembagaan; dan

v. Menentukan kerangka acu€m pengambilan keputusan.

2. Kajian teknis, terdiri dari:

a. Analisis teknis, yang bertujuan untuk:

i. Menetapkan standar kinerja teknis operasional yang diperlukan;

ii. Mempertimbangkan berbagai alternatif tapak, besaran proyek, kualitas, teknologi dan waktu pelaksanaan;

iii. Menetapkan kapasitas keluaran dan standar operasional yang dibutuhkan, serta menyiapkan rancargan awal yang layak secara teknis;

iv. Mengidentihkasi dan menilai Barang Milik Negara dan/ atau Daerah yang dibutuhkan dan menyiapkan daftar Barang Milik Negara dan/atau Daerah yang akan digunakan untuk pelaksanaan KPBU;

v. Mengidentilikasi ketersediaan pasokan sumber daya untuk keberlangsungan KPBU, apabila diperlukan;

vi. Mengidentifikasi persyaratan dan ketersediaan input paling kurang meliputi sumber daya manusia, bahan baku, pelayanan jasa, akses menuju tapak;

vii. Menentukan perkiraan biaya KPBU dan asumsi perhitungan biaya KPBU;

viii. Memperkirakan dan menentukan pendapatan (revenue), biaya modal, biaya operasional dan biaya pemeliharaan dengan berbagai pilihan;

ix. Menyiapkan rencana pembiayaan yang sesuai dengan jadwal konstruksi, perkiraan biaya operasional, perkiraan biaya pemeliharaan, dan estimasi biaya siklus kesinambungan KPBU; dan

x. Mengidentifikasi standar pelayanan minimum. b. Penyiapan tapak termasuk jalur, apabila diperlukan, yang dilakukan dengan mempertimbangkan:

i. Kesesuaian tapat dengal Rencana Tata Ruang Wilayah (RTRW);

ii. Kesesuaian tapak dengan kebutuhan operasional dan bahan baku;

iii. Ketersediaan pelayanan jasa dan bahan baku;

iv. Kondisi tapak yang diusulkan dan kesesuaian dengan kebutuhan KPBU;

v. Konfirmasi kepemilikan tanah dan hambatan-hambatan yang timbul;

vi. Perkiraan biaya pengadaan tanah dengan berbagai pilihan; dan

vii. Rencana dan jadwal pelaksalaan program pengadaan tanah dan pemukiman kembali.

c. Rancang bangun awal, yang memuat rancangan teknis dasar KPBU termasuk lingkup KPBU yang disesuaikan dengan kebutuhan dan karakteristik dari masing-masing sektor;

d. Spesilikasi keluaran, yang meliputi:

i. Standar pelayanan minimum yang meliputi kuantitas, kualitas dan ketersediaan (availability);

ii. Jadwal indikatif untuk pekery'aan konstruksi dan penyediaan peralatan;

iii. Kepatuhan atas masalah lingkungan, sosial dan keselamatan;

iv. Persyaratan pengalihan aset sesuai pedanjian KPBU; dan

v. Pengaturan pemantauan pada setiap tahapan konstruksi, operasi komersial dan berakhirnya pejanjian KPBU.

3. Kajian ekonomi dan komersial, terdiri dari:

a. Analisis permintaan (demand), yang bertujuan untuk memahami kondisi pengguna layanan. Analisis permintaan ini dilakukan dengan paling kurang memuat:

i. Survei kebutuhan nyata (real demand survey) untuk mendapatkan gambaran yang akurat seperti mengenai perkiraan kebutuhan, ketertarikan, kemauan dan kemampuan pengguna 
untuk membayar, kineq'a pembayaran, serta tingkat pelayanan yang diharapkan; dan

ii. Penentuan sumber dan tingkat pertumbuhan permintaan dengan berbagai skenario (uji elastisitas permintaan).

b. Analisis pasar (market), yang bertujuan untuk mengetahui tingkat ketertarikar industri dan kompetisi. Analisis pasar ini dilakukan dengan paling kuraag memuat:

i. Penyampaian rencana KPBU kepada publik dalam rangka Penjajakan Minat Pasar (Market Sounding) calon investor terhadap KPBU;

ii. Pengumpulan tanggapan dan penilaian calon investor terhadap kelayakan, risiko serta kebutuhaa Dukungan Pemerintah dan/atau Jaminan Pemerintah untuk KPBU;

iii. Pengumpulan tanggapan dan penilaian lembaga keuangan nasional dan internasional dan/ atau institusi lainnya mengenai potensi pemberian dan indikasi besaral pinjaman yartg bisa dialokasikan dalam KPBU;

iv. Pemilihan strategi untuk mengurangi risiko pasar dan meningkatkan persaingan yang sehat dalam proses pengadaan KPBU; dan

v. Penilaian mengenai struktur pasar untuk menentukan tingkat kompetisi pada sektor yang bersangkutan.

c. Analisis Biaya Manfaat Sosial (ABMS) yang bertujuan untuk memastikan manfaat sosial dan ekonomi serta keberlanjutan KPBU yang berkaitan dengan efektivitas, ketepatan waktu, penggunaan dana, dan sumber daya publik selama masa KPBU, selain itu ABMS juga dimaksudkan untuk memberikan batasan maksimal besarnya Dukungan Pemerintah, sehingga manfaat bersih KPBU lebih besar dari Dukungan Pemerintah yang diberikan.

d. Analisis struktur pendapatan KPBU, yang bertujuan untuk mengidentilikasi sumber pendapatan yang optimal bagi KPBU dengan mempertimbangkan hasil analisis permintaan, kemampuan pembiayaan kementerian lembaga/ daerah yang bersangkutan, serta tingkat kelayakan KPBU selama masa KPBU.

e. Analisis keuangan, dilakukaa dengan memenuhi ketentuan sebagai berikut:

i. Analisis keuangan bertujuan untuk menentukan kelayakan finansial KPBU dengan menggunakan asumsi;

ii. Analisis keuangan;

f. Analisis Nilai Manfaat Uang (Value for Money) secara kuantitatif yang bertujuan untuk memperkirakaa perbandingan nilai manfaat uarg skema pembiayaan KPBU dengan skema pembiayaan konvensional.

4. Kajian lingkungan dan sosial, terdiri dari:

a. Kajian lingkungan hidup bagi KPBU yang wajib AMDAL, yang dilakukan mengikuti ketentuan sebagai berikut:

i. Melakukan penapisan;

ii. Penyeleksian digunakan sebagai dasar pertimbangan untuk menyusun Kerangka Acuan Analisis Dampak Lingkungan (KA-ANDAL);

iii. Prosedur dalam melakukan kajian dampak lingkungan dilakukan sesuai dengan ketentuan peraturan perundangundangaa di bidang lingkungan hidup;

iv. PJPK bertanggungjawab untuk menyusun dokumen AMDAL bagi KPBU yang terdiri dari KAANDAL, Analisis Dampak Lingkungan (ANDAL), Rencana Pengelolaan Lingkungan Hidup atau Rencana Pemantauan Lingkungan Hidup (RKLRPL) sebagai dasar penilaian dan izin lingkungan dari Menteri/ Kepala Daerah sesuai dengan kewenangannya.

b. Kajian lingkungan hidup bagi KPBU yang wajib memiliki UKLUPL;

c. Analisis sosial, diperlukan untuk:

i. Menentukan dampak sosial KPBU terhadap masyarakat dan menyusun rencara mitigasinya;

ii. Menentukan lembaga yang bertanggung jawab untuk pembebasan tanah dan pemukiman kembali; 
iii. Menentukan pihak-pihak yang akan terkena dampak oleh proyek dan kompensasi yang akan diberikan, bila diperlukan;

iv. Memperkirakan kapasitas lembaga untuk membayar kompensasi dan melaksanakan rencana pemukiman kembali, apabila diperlukan; dan

v. Menentukan rencara pelatihan dalam rangka melaksanakan program perlindungan sosial untuk meningkatkan kapasitas masyarakat yang terkena dampak

d. Rencana pengadaan talah dan pemukiman Kembali.

5. Kajian bentuk KPBU dalam Penyediaaa Infrastruktur, terdiri dari;

a. Pemilihan bentuk KPBU dilalukan dengaa mempertimbangkan faktor sebagai berikut:
i. Kepastian ketersediaan Infrastruktur tepat pada waktunya;

ii. Optimalisasi investasi oleh Badan Usaha;

iii. Maksimalisasi efisiensi yang diharapkan dari pengusahaan Infrastruktur oleh Badan Usaha;

iv. Kemampuan Badan Usaha untuk melakukan traasaksi;

v. Alokasi resiko; dan

vi. Kepastian adanya pengalihan keterampilan manajemen dan teknis dari sektor swasta kepada sektor publik.

b. Bentuk KPBU harus mencakup paling kurang:

i. Lingkup KPBU, mencakup Sebagian atau selurut proses kegiatan KPBU seperti pembiayaan, merancang, membangun, merehabilitasi, mengoprasikan, memelihata, dan lainnya;

ii. Jangka waktu dan penahapan KPBU;

iii. Identifikasi keterlibatan pihak ketiga seperti off-taker, penyedia bahan baku dan lainnya; iv. Skema pemanfaatan Barang Milik Negara danlatau Baralg Milik Daerah selama perjanjian KPBU;

v. Status kepemilikan aset KPBU selama jangka waktu perjanjian KPBU dan pengalihan aset setelah berakhirnya peq'anjian KPBU; dan

vi. Bentuk partisipasi Pemerintah dalam Badan Usaha Pelaksana KPBU, seperti penyertaan modal atau bentuk lainnya

6. Kajian risiko, terdiri dari:

a. Analisis risiko bertujuan untuk meningkatkan nilai tambah bagi para pemangku kepentingan;

b. Analisis risiko dilakukan dengan cara:

i. Melakukan identifikasi risiko;

ii. Mengukur besaran risiko;

iii. Menentukan alokasi risiko;

iv. menyusun mitigasi risiko.

7. Kajian kebutuhan Dukungan Pemerintah dan/atau Jaminan Pemerintah meliputi:

a. Analisis Dukungan Pemerintah, yang bertujuan untuk mengidentifikasi perlu atau tidaknya Dukungan Pemerintah guna meningkatkan kelayakal keuangan KPBU;

b. Dukungan Pemerintah dapat diberikan dalam bentuk:

i. Dukungan kelayatan KPBU (Viability Gap Fund) yang diatur lebih lanjut oleh Peraturan Menteri Keuangan;

ii. Insentif perpajalan; dan/atau

iii. Dukungan Pemerintah dalam bentuk lainnya sesuai dengan ketentuan peraturan perundalg undangan;

c. Analisis Jaminan Pemerintah yang bertujuan untuk mengidentifikasi perlu atau tidalnya Jaminan Pemerintah untuk mengurangi risiko Badan Usaha yang dapat diberikan oleh Menteri Keuangan melalui BUPI sesuai dengan peraturan perundangundangan.

8. Kajian mengenai masalah yang perlu ditindatlanjuti (outstanding issues). 
Pada tahap penyiapan juga dilakukan Konsultasi Publik yang bertujuan untuk menjajaki kepatuhan terhadap norma sosial dan norna lingkungan sesuai dengan ketentuan peraturan perundang-undangan, memperoleh masukan mengenai kebutuhan masyarakat terkait dengan rencana KPBU yang akan dikerjasamakaa dan masukan pemangku kepentingan lainnya; dan memastikan kesiapan KPBU. Konsultasi Publik pada tahap penyiapan pada praktiknya akan berbeda dengan tahap perencanaan. Seringkali ditahap penyiapan gambaran proyek belum cukup tergambar sehingga Konsultasi Publik di tahap perencanaan hanya berupa pengenalan (sounding) kepada masyarakat/stakeholder terkait. Berbeda dengan tahap penyiapan dimana gambaran proyek sudah lebih terleihat. Sebagai contoh dalam hal pemerintah ingin menghubungkan Kota A dan Kota B dengan menyediakan jalan tol. Maka pada Konsultasi Publik tahap perencanaan yang terjelaskan adalah gambaran makro dari kenapa dibutuhkan penghubung antara Kota A dan Kota B dan kenapa jalan tol yang dipilih dalam sarana penghubung, bukan Kereta Apia tau Bandara. Sedangkan pada Konsultasi Publik Tahap Penyiapan sudah dapat disajikan data teknis dalam penyiapan jalan tol tersebut, misalnya kepastian trase, kepastian panjang dan lebar disetiap seksi pada trase jalan tol, dan kendala-kendala yang dihadapi seperti adanya bangunan eksisting atau kawasan yang dilewati adalah kawasan hutan lindung. Hal tersebut akan berpengaruh terhadap jalannya penyiapan proyek sebab ada pihak lain yang berwenang dalam mengusus atau mengizinkan proyek tetap dilaksanakan.

Dalam tahap penyiapan juga dilakukan penjajakan minat pasar (Market Sounding) dimana tujuan dari kegiatan ini adalah untuk memperoleh masukan, tanggapan maupun minat terhadap KPBU dari calon investor, perbankan, asuransi serta para pelaku pasar dan pemangku kepentingan lainnya. Kegiatan ini sangat penting dilakukan sebagai pertimbangan PJPK dalam melihat kesempurnaan kajian Prastudi Kelayakan. Asumsi perhitungan yang digunakan dalam kajian ekonomi dan finansial dapat dimintakan pandangannya dari sisi calon investor dan calon lander (perbankan) dapat diterima atau tidak. Pada kegiatan ini juga berisikan pemberian informasi kepada calon investor bahwa proyek membutuhkan dukungan dan jaminan proyek dengan segala pertimbangan resikonya.

Untuk Kajian akhir Prastudi Kelayakan (Final Business Case), terdiri dari penyempurnaan data dengan kondisi terkini dan pemutakhiran atas kelayakan dan kesiapan KPBU yang sebelumnya telah tercakup dalam kajian awal Prastudi Kelayakan, termasuk penyelesaian hal yang perlu ditindaklanjuti.

Setelah Dokumen Prastudi Kelayakan disempurnakan, jika PJPK ingin menuju tahap KPBU selanjutnya yaitu transaksi maka Dokumen Prastudi Kelayakan tersebut dapat menjadi dokumen acuan dalam pembuatan dokumen yang dibutuhkan ditahap selanjutnya yaitu Rancangan Dokumen Kualifikasi dan Rancangan Perjanjian KPBU. Secara umum dokumen yang menjadi hasil keluaran dari tahap perencanaan adalah (1) Dokumen Prastudi Kelayakan; (2) Dokumen Lingkungan; (3) Rancangan Dokumen Lelang (Pra dan Kualifikasi); (4) Rancangan Perjanjian KPBU.

Terkait dengan KPBU atas prakarsa Badan Usaha (Unsolicited) terdapat kriteria spesifik tertentu diantaranya:

1. Badan Usaha yang mengajukan dapat berbentuk tunggal ataupun konsorsium yang memenuhi kualifikasi yang diusulkan dalam rencana dokumen pengadaan;

2. Dalam hal Badan Usaha Asing, dapat mengajukan Surat Pernyataan Maksud (Letter of Intent) tanpa harus mendirikan perusahaan di Indonesia terlebih dahulu dan calon PJPK dapat mensyaratkan Badan Hukum Asing untuk membentuk konsorsium dengan perusahaan dalam negeri pada saat menyampaikan Dokumen Studi Kelayakan; dan syarat KPBU diantaranya:

a. Terintegrasi secara teknis dengan rencana induk pada sektor yang bersangkutan; 
b. Layak secara ekonomi dan linansial; dan

c. Badan Usaha yang mengajukan prakarsa memiliki kemampuan keuangan yang memadai untuk membiayai pelaksanaan Penyediaan Infrastruktur.

Tahapan/proses persetujuan usulan KPBU atas Prakarsa Badan Usaha terdiri dari:

1. Calon Pemrakarsa menyampaikan surat pernyataan maksud (letter of intent) untuk mengajukan usulan proyek KPBU kepada Menteri/Kepala Lembaga/Kepala Daerah disertai dengan Prastudi Kelayakan;

2. Menteri/ Kepala Lembaga/Kepala Daerah menilai Prastudi Kelayakan (30 hari kerja);

3. Menteri/Kepala Lembaga/Kepala Daerah melaksaaakaa konsultasi publik sebagai bahan pertimbangan penilaian;

4. Menteri/ Kepala Lembaga/ Kepala Daerah membuat keputusan diterima / ditolaknya usulan kerja sama dan Prastudi Kelayakan. Jika diterima maka persetujuan memuat:
a. hak eksklusif Calon Pemrakarsa selama jangka waktu tertentu untuk menyelesaikan Studi Kelayakan KPBU;
b. kewajiban untuk menyiapkan Studi Kelayakan dan mematuhi tata cara KPBU atas prakarsa Badan Usaha sesuai dengan Panduan Umum; dan
c. kewajibaa untuk menyampaikan usulan bentuk kompensasi.

5. Calon Pemrakarsa melanjutkan penyelesaian Studi Kelayakan dan menyerahkannya kepada Menteri/ Kepala Lembaga/Kepala Daerah untuk setelahnya termasuk dokumen terkait lainnya;

6. Menteri/ Kepala Lembaga/ Kepala Daerah mengevaluasi dan menilai secara mendalam Dokumen Studi Kelayalan (60 hari kerja) dan kualifikasi calon pemrakarsa;

7. Menteri/Kepala Lembaga/Kepala Daerah dapat melaksanakan konsultasi publik kembali dan Konfirmasi Pasar sebelum membuat persetujuan terhadap Studi
Kelayakan yang disampaikan Calon Pemrakarsa serta berkonsultasi dengan Badan Usaha Penjaminan Infrastruktur;

8. Menteri/ Kepala Lembaga/ Kepala Daerah membuat keputusan persetujuan dokumen studi kelayakan dan lulusnya kualifikasi badan usaha. Jika disetujui maka persetujuan memuat:

a. persetujuan Studi Kelayakan;

b. penetapan usulan KPBU sebagai KPBU atas prakarsa Badan Usaha

c. penetapan Calon Pemralarsa sebagai Badan Usaha Pemrakarsa;

d. penetapan bentuk kompensasi (pemberian nilai tambah 10\%, right to match, atau pembelian prakarsa); dan

e. persetujuan Rencana Dokumen Pengadaan termasuk pemenuhan persyratan prakualifikasi pengadaan Badan Usaha Pelaksanakewajibaa untuk menyampaikan usulan bentuk kompensasi

9. Tahap pengadaan/pemilihan basan usaha yang tata caranya serupa dengan pengadaan badan usaha pelaksana atas prakarsa pemerintah;

10. Penandatanganan perjanjian KPBU.

Dapat terlihat bahwa penyiapan Dokumen Penyiapan KPBU atas prakarsa Badan Usaha juga terdiri dari 2 tahap yaitu Dokumen Prastudi Kelayakan dan Dokumen Studi Kelayakan. Dalam hal pula terdapat ketentuan bahwa Badan Usaha calon pemrakarsa dapat langsung menyerahkan dokumen studi kelayakan atas dasar kenan dari Badan Usaha itu sendiri. Hal ini dilakukan atas dasar pada praktiknya sudah terdapat penyiapan dokumen yang cukup matang disektor tertentu seperti Jalan Tol dan pertimbangan keleluasaan bagi badan usaha dalam mengeluarkan biaya untuk penyiapan dokumen prakarsa KPBU.

Secara keseluruhan, dokumen yang dihasilkan pada pelaksanaan Proyek KPBU atas Prakarsa Badan Usaha antara lain:

1. Dokumen Prastudi Kelayakan;

2. Dokumen Studi Kelayakan;

3. Dokumen AMDAL (KA ANDAL, Rencana Pengelolaan Lingkungan 
Hidup/Pemantauan Lingkungan Hidup) atau formulir UKL-UPL diisi;

4. Dokumen rencana pengadaal tanah dan pemukiman Kembali;

5. Dokumen Studi Kelayakaan;

6. Dokumen permintaan penawaran;

7. Dokumen perjanjian KPBU;

8. Dokumen perjanjian penjaminan dan Dokumen perjanjian regres (jika menggunakan).

\section{Pembelajaran (Lesson Learn)}

Pada praktiknya, penyiapan proyek KPBU dapat dikatakan memiliki faktor penentu yang dapat berpengaruh besar terhadap kelancaran penyiapan proyek. Faktor penentu tersebut berbeda-beda disetiap proyeknya, mengingat bahwa proyek memiliki banyak sektor yang diatur oleh peraturan sektor tersendiri serta terdapat regulasi lain yang mengikat hanya di beberapa kondisi tertentu, contohnya proyek dengan PJPK Pemerintah Daerah yang memiliki regulasi yang diatur Peraturan Menteri Dalam Negeri dan Peraturan Pemerintah tentang Kerja Sama Daerah. Sebagai contoh Proyek SPAM Umbulan yang dimiliki oleh (PJPK) Gubernur Jawa Timur dimana memiliki faktor penentu yaitu keputusan pimpinan stakeholder terkait dalam memberikan kebutuhan proyek itu sendiri. Proyek SPAM Umbulan merupakan salah satu proyek yang memiliki kisah sukses dimana berhasil menggabungkan/ mempertemukan 6 sumber pembiayaan diantaranya ekuitas dan hutang badan usaha, dukungan pemerintah pusat berupa fasilitas VGF dan DAK Kementerian Kauangan, dukungan sebagian konstruksi Kementerian PUPR dan dukungan dari pemerintah daerah. Bahkan proyek tersebut mendapat beberapa penghargaan dan dijadikan sebagai proyek percontohan. Pemberian keputusan dukungan pemerintah tidak lepas dari adanya koordinasi tingkat pimpinan yang terus diselenggarakan demi kelancaran dan terealisasinya proyek tersebut. Contoh lain hadir dari Kementerian Komunikasi dan Informasi dengan proyek Palapa Ring, yaitu proyek penyediaan infrastruktur jaringan fibber optic yang membentang diseluruh wilayah Indonesia.
Proyek Palapa Ring sendiri terbagi menjadi 3 Paket yaitu Paket Barat, Paket Tengah dan Paket Timur. Sampai saat ini, Proyek Palapa Ring memegang perencanaan dan penyiapan tercepat yaitu 18 bulan. Hal ini tidak lepas dari peran Menteri Kominfo yang menjadi faktor penentu dimana beliau selalu turut mendampingi dalam penyiapannya, sehingga segala keputusan dan kebutuhan dapat cepat terakomodir.

Tidak semua Proyek KPBU berjalan dengan lancar bahkan hingga menciptakan terhentinya proyek. Sebagai contoh terdapat 2 (dua) proyek daerah yaitu Rumah Sakit Sidoarjo dan Rumah Sakit Pirngadi Medan yang sampai saat ini terhenti akibat tidak disetujuinya proyek tersebut oleh Anggota DPRD. Hal tersebut menjadi salah satu faktor penentu kelancaran proyek pada contoh proyek ini. Regulasi kerja sama daerah dan peraturan Kementerian Dalam Negeri mensyaratkan hal tersebut sebagai bagian dari prores kerja sama. Diperlukan pendekatan politis untuk menjadi pemecah thebottleneck. Akan sangat disayangkan proyek disektor kesehatan yang dibutuhkan akibat adanya pandemi Covid-19 harus terhenti akibat kurangnya dukungan dan fasilitasi pemerintah.

Lebih lanjut hambatan proyek juga terjadi para proyek KPBU Unsolicited, contohnya Bandara Udara Kediri dan TOD Poris Plawad. Penyiapan Studi Bandara Udara Kediri sudah dilaksanakan sejak tahun 2019 dan beberapa kali terkendala oleh persoalan regulasi, diantaranya waktu pendirian badan usaha pelaksana, izin kebandarudaraan (BUBU), dokumen prakarsa (DED), dan lain sebagainya. Pembahasan isu tersebut terus berlangsung sampai saat ini dimana peran penting pembahasan di level pimpinan menjadi ujung tombak dalam penyelesaiannya. Peran penting percepatan pengambilan keputusan di tingkat pimpinan akhirnya diterapkan juga pada proyek lain seperti TOD Poris Plawad yang mengalami permasalahan teknis dan regulasi. Badan usaha pemrakarsa yang mengusulkan prosposal tidak mengikuti syarat sesuai regulasi menjadi permasalahan sejak dini yang berimpas pada proses dibelakangnya. Pemerintah selaku PJPK 
memerlukan pertimbangan hukum, teknis dan finansial untuk menerima suatu proyek agar dapat diselenggarakan. Secara keseluruhan regulasi di Indonesia sudah cukup mengatur penyelenggaraan Proyek TOD, hanya saja terdapat kasus dimana badan usaha tidak mematuhi aturan sehingga memerlukan pendampingan dalam prosesnya. Sebagai contoh kurangnya kajian teknis dan finansial membuat pihak pemerintah belum teryakinkan untuk proyek sendiri dan setelah di kaji lebih dalam menimbulkan permasalahanpermasalahan yang lain. Pada Proyek TOD terdapat permasalahan teknis berupa ketinggian gedung yang melebihi batas regulasi akibat lokasi berada pada jangkauan/area bandara membuat ketinggian bangunan harus dikurangi dan membuat perhitungan finansial proyek menjadi tidak layak. Dari permasalahan tersebut membuat proses proyek berlarut-larut dan badan usaha selalu bernegosiasi dengan kajian teknis tersendiri. Hal tersebut dapat saja dibenarkan, namun dengan regulasi yang sudah ada pemerintah sulit menentukan kajian yang tepat dan resiko perubahan regulasi akan memakan biaya dipihak pemerintah sendiri. Oleh sebab itu kecenderungan pemerintah menaati regulasi yang ada menjadi besar dan membuat rencana investasi tidak berjalan sesuai perancanaan dari segi badan usaha.

Pemerintah dapat mengambil peran lebih terhadap kasus-kasus diatas. Pintu gerbang investasi sebagai penyambut investor harus dipunggawai oleh instansi yang mengetahui seluk-beluk skema investasi dan memiliki akses cepat kepada pengambil keputusan. Pemerintah memiliki wadah berkumpulnya para pemangku kepentingan pelaksana KPBU yang dikenal dengan Kantor Bersama KPBU Republik Indonesia (PPP Joint Office) dimana berisikan 7 Kementerian/Lembaga yang terdiri dari Kementerian Koordinator Bidang Perekonomian, Kementerian Koordinator Bidang Kemaritiman dan Investasi, Kementerian Keuangan, Kementerian Dalam Negeri, Kementerian Perencanaan Pembangunan Nasional, Badan Koordinasi Penanaman Modal, dan Lembaga Kebijakan
Pengadaa Barang/Jasa. Nota Kesepahaman sudah ditandatangani di Tahun 2020 yang menjadi bukti komitmen pemerintah dalam menangani kerja sama investasi pemerintah dan badan usaha. Kantor Bersama memiliki potensi untuk lebih dioptimalkan dalam mengurai hambatan-hambatan pelaksanaan KPBU.

Pembelajaran yang dapat diambil dari pembahasan sebelumnya adalah harus ada perhatian lebih dari para pengambil keputusan untuk selalu hadir dan mengetahui perencanaan dan penyiapan proyek yang menggunakan skema KPBU. Hadirnya pengambil keputusan dalam perencanaan dan penyiapan KPBU menjadi salah satu cara percepatan penyelenggaraan pelaksanan KPBU, karena masalah yang sering timbul terutama pada tahap penyiapan akan langsung terurai atau setidaknya dikelola langsung oleh pimpinan sehingga dalam menentukan langkah yang perlu diambil tidak memakan waktu yang berlarut-larut. Hal ini sangat penting dilakukan mengingat yang akan menanggung kerugiannya adalah masyarakat sendiri akibat tidak tersedianya layanan yang dibutuhkan.

Dalam contoh kasus TOD Poris Plawad yang dilaksanakan dengan skema KPBU Unsolicited, pemerintah lewat Kantor Bersama dapat menjadi titik pertemuan pertama investor yang dibawa oleh PJPK dalam hal ini Kementerian Perhubungan c.q Badan Pengelola Transportasi Jabodetabek. Kesadaran siapapun PJPK nantinya perlu disepahami sebelumnya untuk membawa calon investor ke Kantor Bersama. Tujuannya adalah untuk memperkenalkan stakeholder terkait, menyaring pemenuhan sejak awal, dan memitigasi resiko kesalahan/kekurangan dikemudian hari.

Pada perkembangannya Proyek KPBU atas Prakarsa Pemerintah di Indonesia saat ini berjumlah:

1. 4 proyek di tahap perencanaan dengan kisaran nilai sebesar Rp 19,2 Triliun;

2. 45 proyek di tahap penyiapan dengan kisaran nilai sebesar Rp 259,6 Triliun;

3. 14 proyek di tahap transaksi dengan kisaran nilai sebesar Rp 107,6 Triliun; 
4. 9 proyek sedang konstruksi dengan kisaran nilai sebesar Rp 106,2 Triliun;

5. 7 proyek sudah beroperasi dengan kisaran nilai sebesar Rp 38,9 Triliun.

Sementara untuk Proyek KPBU atas

Prakarsa Badan Usaha di Indonesia saat ini berjumlah:

1. 3 proyek di tahap penyusunan dokumen penyiapan dengan kisaran nilai sebesar $\mathrm{Rp}$ 13,7 Triliun;

2. 10 proyek di tahap persetujuan dokumen prakarsa dengan kisaran nilai sebesar Rp 130,3 Triliun;

3. 5 proyek di tahap transaksi dengan kisaran nilai sebesar Rp 101 Triliun;

4. 3 proyek sedang konstruksi dengan kisaran nilai sebesar Rp 36,6 Triliun;

5. 1 proyek sudah beroperasi dengan kisaran nilai sebesar Rp 24,7 Triliun

\section{DAFTAR PUSTAKA}

Agustiyanti. (2019). Peringkat Daya Saing Indonesia Turun, Makin Tertinggal dari Malaysia. Katadata.co.id. https://katadata.co.id/berita/2019/1 0/10/peringkat-daya-saingindonesia-turun-makin-tertinggaldari-malaysia.

Heripoerwanto, Eko Djoeli. (2019). Direktur Jenderal Pembiayaan Infrastruktur Kementerian PUPR.

Indonesia. Undang-Undang Nomor 25 Tahun 2004 tentang Sistem Perencanaan Pembangunan Nasional.

Indonesia. Peraturan Presiden Nomor 79 Tahun 2017 tentang Rencana Kerja Pemerintah Tahun 2018.

Indonesia. Peraturan Presiden Nomor 18 Tahun 2020 tentang Rencana Pembangunan Jangka Menengah Nasional Tahun 2020-2024.

Indonesia. Peraturan Presiden Nomor 38 Tahun 2015 tentang Kerjasama Pemerintah Dengan Badan Usaha Dalam Penyediaan Infrastruktur.

Indonesia. Peraturan Menteri Menteri Perencanaan Pembanginan Nasional Nomor 2 Tahun 2020 tentang Perubahan Atas Peraturan
Menteri Perencanaan Pembangunan Nasional Nomor 4 Tahun 2015 tentang Tata Cara Kerjasama Pemerintah Dengan Badan Usaha Dalam Penyediaan Infrastruktur.

Kementerian Perencanaan Pembangunan Nasional (Bappenas). (2020). Evaluasi Paruh Waktu RPJMN 2015 - 2019, dan Narasi Rencana Kerja Pemerintah Tahun 2016.

Palupie, Yudhitya Maharani Ristian dan Hari Agung Yuniarto. (2016). Alokasi Resiko Proyek Infrastruktur Dengan Skema Kerjasama Pemerintah dan Badan Usaha $(K P B U)$ : Suatu Tinjauan Literatur. Fakultas Teknik Universitas Gadjah Mada.

Rantung, Ferdi. (2018). Peringkat 72 seAsia, Stok Infrastruktur RI Jauh dari Starndar Internasional. Ekbis.sindonews.com.

https://ekbis.sindonews.com/read/9 7708/34/peringkat-72-se-asia-stokinfrastruktur-ri-jauh-dari-standarinternasional-1594458432

Setiawan, Sakina Rakhma Diah. (2019). Indonesia Kini Jadi Negara Berpendapatan Menengah ke Atas. Kompas.com. https://ekonomi.kompas.com/read/ 2019/02/08/064308426/indonesiakini-jadi-negara-berpendapatanmenengah-ke-atas

\begin{tabular}{cc}
\hline World $\begin{array}{c}\text { Bank. } \\
\text { www.datacatalog.worldbank.org/da }\end{array}$ \\
taset/gdp-ranking
\end{tabular}

